\title{
Helicobacter pylori enfeksiyonu tanısında kullanılan invaziv yöntemlerin duyarlılık ve özgüllüklerinin değerlendirilmesi
}

\author{
Evaluation of the sensitivity and specificity of invasive methods used in the diagnosis of \\ Helicobacter pylori infection
}

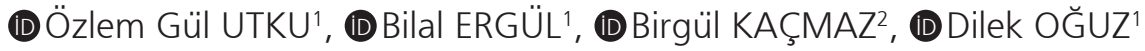

Kırıkkale Üniversitesi ${ }^{1}$ Iç Hastalıkları Anabilim Dalı Gastroenteroloji ve Hepatoloji Bölümü ${ }^{2}$ Klinik Mikrobiyoloji ve Enfeksiyon Anabilim Dalı, Kırıkkale

Giriş ve Amaç: Helicobacter pylori yaklaşık 3.5 mikron uzunluğunda ve 0.5 mikron genişliğinde, spiral şekilli, mikroaerofilik, gram negatif bir bakteridir. Dünya popülasyonunun yaklaşık yarısı Helicobacter pylori ile enfektedir. Helicobacter pylori, gastrit, gastrik ve duodenal ülser, gastrik adenokarsinoma ve mukoza ile ilişkili lenfoid doku lenfomasında birincil patojen olarak bildirilmektedir. Bu bakteri gelişmekte olan ülkelerde önemli bir halk sağlığı sorunudur. Helicobacter pylori tanısında endoskopi gerektiren invaziv ve gerektirmeyen noninvaziv tanı testleri mevcuttur. Bunlar; hızlı üreaz testi, histopatolojik inceleme ve kültür invaziv yöntemlerdir. Bu çalışmada amacımız Helicobacter pylori enfeksiyonu için daha önce tedavi almamış hasta grubunda hızlı üreaz testi, histopatolojik değerlendirme ve kültür sonuçlarının karşılaştırılması ve bu yöntemlerin kültür altın standart yöntem olarak değerlendirildiğinde sensitivite ve spesifitelerini belirlemektir. Gereç ve Yöntem: Hastanemiz gastroenteroloji kliniğinde dispepsi ön tanısı ile endoskopi yapılan 18-65 yaş arası 55'i (\%55.6) kadın, 44'ü (\%44.4) erkek toplam 99 hasta çalışmaya alınmıştır. Endoskopide antrumdan kültür, dokuda üreaz ve histopatolojik inceleme için toplam dört biyopsi örneği alınmıştır. Bu örneklerin iki tanesi kültür için kullanılmıştır. Enfeksiyon tanısında altın standart olarak; tek başına kültürün pozitif olması ya da kültürün negatif olduğu durumlarda kullanılan iki testin (histopatolojik inceleme ve hızlı üreaz testi) pozitif olması kabul edilmiştir. Bulgular: Çalışmada 18-65 yaş arası (yaş ortala-

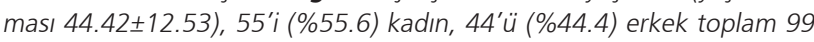
hasta değerlendirilmiştir. Endoskopik olarak 91 (\%92) hastada gastrit, $8(\% 8)$ hastada gastrik ülser tespit edildi. 38 (\%38.3) hastada kültürde üreme, 75 (\%75.7) hastada hızlı üreaz testi pozitifliği ve 71 (\%71.7) hastada histopatolojik inceleme pozitifliği bulunmuştur. Buna göre 99 hastanın 63 (\%63.6) tanesinde altın standart kriterlerine göre Helicobacter pylori pozitif bulunmuştur. Hastaların kültür, hızlı üreaz testi ve histopatolojik inceleme yöntemlerinin duyarlılı ve özgüllükleri sırasıyla $\% 60.3$ ve $\% 100, \% 100$ ve $\% 66.6, \% 98.4$ ve $\% 75.0$ olarak saptanmıştır. Sonuç: Helicobacter pylori enfeksiyonu tanısında kullanılan farklı özgüllük ve duyarlılığa sahip birçok yöntem mevcuttur. Ancak bu yöntemler arasından yapılacak olan seçim, amaca ve klinik şartlarına göre değişiklik göstermektedir. Çalışmamızın bulguları, endoskopik yöntemlerin uygulanabildiği durumlarda, erken tanı ve tedavi kararı için hızlı üreaz testi kullanılarak hastalığın tedavisinin planlanabileceğini destekler niteliktedir.

Anahtar kelimeler: Bakteriyel kültür, Helicobacter pylori, hızlı üreaz, histopatoloji

"Bu yayın 7. EKMUD Uluslararası Bilimsel Kongresi, 8-13 Mayıs 2018,

Antalya'da poster olarak sunulmuştur."

iletișim: Özlem GÜL UTKU

Göksu Mah. Erzurum Kongre Cad., Göksu Metrokent sitesi A4/24,

Ankara, Türkiye

E-mail: ozlemgulx@yahoo.com
Background and Aims: Helicobacter pylori is a helical Gram-negative microorganism frequently detected in people worldwide. It is the cause of $90 \%$ of duodenal ulcer cases and $60 \%-70 \%$ of peptic ulcer cases. The World Health Organization also indicated that Helicobacter pylo$r i$ is the most common reason of mucosa-associated lymphoid tissue lymphoma and gastric malignancies. Helicobacter pylori infection is diagnosed by using various methods, such as endoscopy to obtain tissue samples, histopathological evaluation, bacterial culture, rapid urease test, and polymerase chain reaction, but they are invasive methods for the direct detection of pathogens. Our study aimed to compare the diagnostic value of histological examination, bacterial culture, and rapid urease test for detecting Helicobacter pylori infection in untreated patients and to determine the sensitivity, specificity, and negative and positive predictive values of these tests. Materials and Methods: Ninety-nine patients who were examined because of dyspeptic complaints and scheduled for an upper gastrointestinal endoscopic examination were included in this study. Four biopsies (antrum) were obtained from each patient and examined via a rapid urease test, a histopathological evaluation, and a bacterial culture. As the gold standard in the diagnosis of infection, it was accepted that either the culture was positive, if the culture was negative, or the two other tests were both positive. The specificity and sensitivity of these methods were compared. $\boldsymbol{R e}$ sults: Of the 99 biopsy specimens obtained from the patients with dyspeptic complaints, 71 (71.7\%) were positive for Helicobacter pylori during histopathological evaluation, 75 (75.7\%) were positive for Helicobacter pylori during rapid urease test, and 38 (38.3\%) were positive for Helicobacter pylori during bacterial culture. The sensitivity and specificity of the tests were as follows: rapid urease test, $100 \%$ and $66.6 \%$; histopathological evaluation, 98.4\% and 75.0\%; and bacterial culture, $60.3 \%$ and $100 \%$. Conclusion: The diagnostic methods used to identify Helicobacter pylori infection were compared, and results indicated that in comparison with bacterial culturing as the gold standard for the detection of Helicobacter pylori infection. This study showed that disease treatments could be planned by conducting a rapid urease test for early diagnosis, and treatment decision could be made through endoscopic methods.

Keywords: Bacterial culture, Helicobacter pylori, histopathology, rapid urease test

Utku ÖG, Ergül B, Kaçmaz B, et al. Evaluation of the sensitivity and specificity of invasive methods used in the diagnosis of Helicobacter pylori infection. The Turkish Journal of Academic Gastroenterology 2020;19:1-4. DOI: 10.17941/agd.705695

Geliş Tarihi: 26.10.2018 • Kabul Tarihi: 20.12.2019 


\section{GíRiş}

Helicobacter pylori (H. pylori), yaklaşık 3.5 mikron uzunluğunda ve 0.5 mikron genişliğinde, spiral şekilli, mikroaerofilik, gram negatif bir bakteridir. In vitro olarak yavaş büyüyen bir mikroorganizmadır. Kanlı agar veya Skirrow's agar gibi özel besi yerlerinde $37{ }^{\circ} \mathrm{C}^{\prime}$ de $\% 5$ oksijenli hava ortamında üç ile yedi gün arasında inkübe edilerek kültürü yapılabilir. Küçük, eşit boyutlu, yarı saydam bakteri kolonileri oluşturur. Organizmalar morfolojik olarak Gram boyası ile tipik spiral veya çubuk şeklinde görülür. Elektron mikroskopunda iki ile yedi arasında hareketli flajellaya sahip olduğu görülür. İnsanda en fazla enfeksiyon oluşturan mikroorganizmadır ve dünya nüfusunun $\% 50$ 'den fazlası bu bakteri ile enfektedir (1). Gelişmekte olan ülkelerde \%60-85 arasında değişen prevalans, gelişmiş ülkelerde kişisel hijyene verilen önem ve yapılan başarılı eradikasyon çalışmalarıyla \%10-30'lara kadar geriletilmiştir. Kronik gastritis, peptik ülser, mide kanseri, MALToma (Mucosa Associated Lymphoid Tumor/Gastrik Lenfoma) gibi patolojilere neden olmaktadır. Ayrıca anemiler, arterit, ateroskleroz ve immün trombositepenik purpura gibi önemli hastalıklarla etiyolojik ilişkisi tartışılmaktadır (2). Helicobacter pylori tanısında kullanılan testler invaziv testler ve non-invaziv testler olmak üzere ikiye ayrılır. Invaziv yöntemler; üst gastrointestinal endoskopi ile antrum ve korpustan alınan biyopsi örneklerinden üreaz aktivitesi, histopatolojik inceleme (HPi), kültür ve polimeraz zincir reaksiyonu (Polymerase Chain Reaction; $P C R$ ) yöntemleri ile bakterinin tespitini sağlayan testlerdir. Non-invaziv testler ise seroloji, ${ }^{13} \mathrm{C}$ ve ${ }^{14} \mathrm{C}$ üre nefes testleri (ÜNT), "Helicobacter pylori Stool antigen test" (HpSA)'dan oluşmaktadır (3).

Bu çalışmada; dispepsi ön tanısı ile endoskopi yapılan hastaların biyopsi örneklerinde $H$. pylori varlığının üreaz, HPi ve kültür yöntemleri ile değerlendirilmesi ve bu yöntemlerin duyarlıık ve özgüllüklerinin karşılaştırılması amaçlanmıştır.

\section{GEREÇ ve YÖNTEM}

Hastanemiz gastroenteroloji kliniğinde dispepsi ön tanısı ile endoskopi yapılan 18-65 yaş arası 55'i (\%55.6) kadın, 44'ü (\%44.4) erkek toplam 99 hasta çalışmaya alınmıştır. Endoskopi işleminden bir ay öncesi herhangi bir antibiyotik tedavisi alanlar, önceden $H$. pylori eradikasyon tedavisi almış olanlar, bizmut içeren bileşiklerle veya 1 hafta öncesine kadar proton pompa inhibitörü ile tedavi gören olgular çalışmaya alınmamıştır. Ayrıca gebe, laktasyonda olan ve ciddi sistemik enfeksiyonlu hastalar çalışmaya alınmamıştır. Endoskopide, antrumdan ikisi kültür bir ta- nesi dokuda üreaz ve bir tanesi HPI için olmak üzere dört biyopsi örneği alınmıştır. HPI ve hızlı üreaz testinin birlikte pozitif olması ya da tek başına kültürün pozitif olması $H$. pylori enfeksiyonu tanısı için altın standart olarak kabul edilmiştir.

\section{Kültür}

Kültür için kullanılacak biyopsi örnekleri en geç 1 saat içinde laboratuvara ulaştıııldı. Biyopsi örnekleri; selektif (\%10 steril at kanı+vankomisin+nalidiksik asit+trimetoprim ilaveli Columbia agar Oxoid) ve non-spesifik (kanlı agar ve endo agar) agar plaklarına steril koşullarda ekim yapılmıştır ve $37{ }^{\circ} \mathrm{C}^{\prime}$ de mikro-aerofilik (\%5-10 CO $\mathrm{CO}_{2}$ ) ortamda beş-yedi gün tutulmuşlardır. Üçüncü günden sonra her gün üreme olup olmadığı kontrol edildi. Yedinci gün sonunda halen üreme olmadıysa negatif olarak kabul edildi. Besi yerinde su damlası şeklinde, 0.5-1 mm çapında, şeffaf ve düzgün kenarlı olarak üreyen koloniler değerlendirildi. Bu kolonilerden yapılan Gram boyama sonunda, gram-negatif kıvrık basillerin görülmesi $H$. pylori varlığını düşündürdü.

\section{Histopatoloji}

Biyopsi örneklerinden hematoksilen-eozin (HE) boyanması ile Giemsa boyaması yapılarak $H$. pylori saptama amaçlanmıştır. Bu çalışmada Sydney sınıflaması temel alınmışıır.

\section{Dokuda Üreaz Saptama}

Biyopsi örneklerindeki H. pylori'nin üreaz aktivasyonunun saptanması için üreaz test kiti kullanılmıştır. Beş dakikada sarı renkten kırmızıya dönüşüm $H$. pylori için pozitif olarak değerlendirilmiştir. Eğer negatiflik varsa, 24 saat beklenerek tekrar değerlendirilmiştir.

\section{Olgularda H. pylori Enfeksiyonu Varlığı}

Olgularda H. pylori enfeksiyonu varlığı; (a) tek başına kültür pozitifliği ve/veya (b) histopatolojik inceleme ve hızlı üreaz testinin her ikisinin pozitif olması durumunda kabul edildi. Kültür, altın standart yöntem olarak alınarak histopatoloji ve hızlı üreaz testi testinin duyarlıık ve özgüllük değerleri belirlendi

Verilerde örnek sayısı n olarak gösterildi ve yüzde olarak hesaplandı. İstatistiki testler için SPSS Windows 16 programı kullanıldı. Duyarlılık, özgüllük, negatif ve pozitif prediktif değerleri excell-2010 programında hesaplandı.

\section{BULGULAR}

Çalışmada 18-65 yaş arası (yaş ortalaması 44.42 \pm 12.53 ) $55^{\prime} \mathrm{i}$ (\%55.6) kadın, 44'ü (\%44.4) erkek toplam 99 hasta 
Tablo 1. Hastaların demografik verileri

\begin{tabular}{|c|c|c|}
\hline \multicolumn{2}{|l|}{ Değişkenler } & Total \\
\hline \multicolumn{2}{|l|}{ Yaş ort \pm std* } & $44.42 \pm 12.53$ \\
\hline \multicolumn{3}{|l|}{ Cinsiyet n (\%) } \\
\hline & Kadın & $55(\% 55.6)$ \\
\hline & Erkek & $44(\% 44.4)$ \\
\hline \multicolumn{3}{|c|}{ Endoskopik tanı n (\%) } \\
\hline & Gastrit & $91(\% 92)$ \\
\hline & Gastrit + Gastrik Ülser & $8(\% 8)$ \\
\hline
\end{tabular}

değerlendirilmiştir. Endoskopik olarak 91 (\%92) hastada yalnızca gastrit, $8(\% 8)$ hastada gastrit ve gastrik ülser tespit edildi (Tablo 1). 38 (\%38.3) hastada kültürde üreme, 75 (\%75.7) hastada hızlı üreaz testi pozitifliği ve 71 (\%71.7) hastada HPI ile H. pylori pozitifliği bulunmuştur. Enfeksiyon tanısında; tek başına kültürün pozitif olması ya da kültürün negatif olduğu durumlarda kullanılan iki testin (HPi ve hızı üreaz testi) pozitif olması altın standart olarak kabul edilmiştir. Buna göre 99 hastanın 63 (\%63.6) tanesinde altın standart kriterlerine göre H. pylori pozitif bulunmuştur. Hastaların kültür, hızlı üreaz testi ve HPI yöntemlerinin duyarlılık ve özgüllükleri sırasıyla $\% 60.3$ ve $\% 100, \% 100$ ve $\% 66.6, \% 98.4$ ve $\% 75.0$ olarak saptanmışır (Tablo 2).

\section{TARTISMA}

Dünya popülasyonunun yaklaşık yarısı $H$. pylori ile enfekte olup gelişmekte olan ülkelerde önemli bir halk sağlığı sorunudur. H. pylori tanısında endoskopi gerektiren invaziv ve gerektirmeyen non-invaziv tanı testleri mevcuttur. Her iki grup yönteminin de avantaj ve dezavantajları vardır (4). Hızlı üreaz testi; ucuz ve bakterinin tespitinde erken sonuç almamızı sağlayan bir yöntemdir. Bakterinin gastrik mukozada heterojen dağılması nedeniyle veya hasta yakın zamanda antibiyotik, bizmut içeren ilaçlar, proton pompa inhibitörü kullandıysa bu test yalancı negatif sonuç verebilir. Ayrıca alınan biyopsi örneğinin tükrük ile teması sonucu diğer üreaz içeren bakteriler ile kontamine olursa yalancı pozitiflik durumu ortaya çıkabilir (5-7).
Bu testin duyarlıığı, özgüllüğü ve pozitif prediktif değerleri sırasıyla \%98, \%99 ve \%99 olarak tespit edilmiştir (8). Tseng ve ark. üreaz testi duyarlıığını $\% 95-\% 100$, özgüllüğünü ise \%85-\%95 olarak bulmuşlardır (9). Kültür pozitifliği veya kültürün negatif olduğu durumlarda hızlı üreaz testi ve histolojik incelemenin birlikte pozitifliğin altın standartı olarak kabul edildiği bir çalışmada, hızlı üreaz testinin duyarlıık ve özgüllüğü \%90 ve \%97 tespit edilmiştir (10). Bizim çalışmamızda hızlı üreaz testi pozitiflik oranı \%75, duyarlıı̆ı \%100, özgüllüğü \%66, pozitif prediktif değeri \%84, negatif prediktif değeri 100 olarak tespit edildi. Bulgularımız literatür ile uyumluydu. Hızlı üreaz testi için saptadığımız duyarlılık değeri, diğer çalışmalarla uyumlu olmasına rağmen özgüllüğün çok düşük bulunması; üreaz enzimi oluşturan diğer bakterilerin kontaminasyonu sonucu ortaya çıkan yalancı pozitifliklere bağlandı.

H. pylori'nin histopatolojik değerlendirmesinde değişik boyalar kullanılabilir. Her birinin duyarlıı̆ı ve özgüllüğü farkıdır. HE boyamasında spiral şeklinde bir görüntüsü vardır. HE boyasının duyarlıı̆ı ve özgüllüğü sırasıyla \%6993 ve \%87-90 olarak bildirilmiştir. Bununla birlikte, modifiye Giemsa boyası, Warthin Yıldızlı gümüş rengi boya, Genta boyası ve immünohistokimyasal boyalar gibi özel boyama yöntemleri kullanılarak spesifite \%90-100 oranında iyileştirilebilir (11). Laine ve ark. HE boyası ile duyarlıığı \%70, özgüllüğü ise \%90'ın altında bulmuşlar (12). Bizim çalışmamızda HPI \%71.7 (n: 71) oranında H. pylori pozitif bulundu. Kültürü altın standart olarak aldığımızda HPi'nin duyarlıık ve özgüllüğü sırasıyla \%98.4 ve \%75.0 olarak tespit edildi.

H. pylori tespitinde altın standart olarak kabul gören test kültürdür. H. pylori gastrik mukozada heterojen yerleştiği için birden fazla biyopsi almak gerekir. Kültür sonucunu etkileyen birçok faktör vardır; kanamalı hastalarda kanaması olmayanlara göre kültür sensitivitesi düşüktür, gastrit aktivitesinin yüksek olması, düşük bakteriyel yük, alkol kullanımı, $\mathrm{H}_{2}$ reseptör blokörü kullanımı, enfeksiyonun yeni kazanılmış olması, bakterinin üretilme zorluğunun dışında yanlış negatif sonuçlara neden olabilir (4). Çalışmalarda, biyopsi örneklerinde kültür pozitifliğinin yaklaşık \%30 oranında olduğu belirtilmekte; kültürün duyarılığı \%45-89,

Tablo 2. Mide biyopsi örneklerinde H. pylori tanısında kullanılan yöntemlerin karşılaştırılması

\begin{tabular}{|lccccc}
\hline Yöntem & Pozitiflik (\%) & Duyarlılık (\%) & Özgüllük (\%) & PPD (\%) & NPD (\%) \\
\hline Kültür & 38.3 & 60.3 & 100 & 100 & 59.0 \\
\hline Hızlı üreaz testi & 75.7 & 100 & 66.6 & 84.0 & 100 \\
\hline HPI & 71.7 & 98.4 & 75.0 & 87.3 & 96.4
\end{tabular}

HPI: Histopatolojik inceleme, PPD: Pozitif prediktif değer, NPD: Negatif prediktif değer 
Özgüllüğü \%97-100 olarak verilmektedir (13-16). Aktepe ve ark. histopatolojiyi altın standart olarak kabul edip, kültür yönteminin duyarlılık ve özgüllüğünü sırasıyla \%61 ve \%91 oranında rapor etmişlerdir (17). Ülkemizde çocuk vakalar ile yapılan bir çalışmada histoloji altın standart olarak kabul edildiğinde kültürün duyarlılığı \%54.9, hızlı üreaz testinin duyarlılı̆ı \%89.2 olarak bildirilmiştir (18). Kalem ve ark. kültür yöntemini altın standart olarak aldıklarında, üreaz testinin ve histolojik inceleme yönteminin duyarlılık ve özgüllüklerini sırasıyla; \%97.5 ve \%20.7, \%72.5 ve \%100 olarak bulmuştur (19). Storskrub ve ark.nın yapmış oldukları çalışmada biyopsi örneklerinde $H$. pylori izolasyon oranı \%33 (336/1000) olarak tespit edilmiştir (13). Bizim çalışmamızda kültürde üreme \%38.3 (n: 38), duyarlıık ve özgüllük sırasıyla \%60.3 ve \%100 olarak tespit edildi. Bizim çalışmamızda kültürün özgüllüğünün yüksek, duyarılığının ise diğer yöntemlere göre düşük olduğu saptanmıştır. Bu durum; H. pylori'nin oksijene duyarlı nazlı, güç üreyen bakteri olması, biyopsinin alındığı yer ve taşınma koşulları gibi faktörlerden kaynaklanmış olabilir.

\section{KAYNAKLAR}

1. Linz B, Balloux F, Moodley Y, Manica A, et al. An African origin for the intimate association between humans and Helicobacter pylori. Nature 2007;445:915-8.

2. Malfertheiner P, Selgrad M, Bornschein J. Helicobacter pylori: clinical management. Curr Opin Gastroenterol 2012;28:608-14.

3. Wright $\mathrm{CL}$, Kelly JK. The use of routine special stains for upper gastrointestinal biopsies. Am J Surg Pathol 2006;30:357-61.

4. Lopes Al, Vale FF, Oleastro M. Helicobacter pylori infection - recent developments in diagnosis. World J Gastroenterol 2014;20:9299313.

5. Pourakbari B, Ghazi M, Mahmoudi S, et al. Diagnosis of Helicobacter pylori infection by invasive and noninvasive tests. Braz J Microbiol 2013;44:795-8.

6. Di Rienzo TA, D'Angelo G, Ojetti V, et al. 13C-Urea breath test for the diagnosis of Helicobacter pylori infection. Eur Rev Med Pharmacol Sci 2013;17(Suppl 2):51-8.

7. Skrebinska S, Megraud F, Bessede E. Diagnosis of Helicobacter pylori infection. Helicobacter 2018;23(Suppl 1):e12515.

8. Hunt RH, Xiao SD, Megraud F, et al; World Gastroenterology Organization. Helicobacter pylori in developing countries. World Gastroenterology Organisation Global Guideline. J Gastrointestin Liver Dis 2011;20:299-304.

9. Tseng CA, Wang WM, Wu DC. Comparison of the clinical feasibility of three rapid urease tests in the diagnosis of Helicobacter pylori infection. Dig Dis Sci 2005;50:449-52.

10. Lage AP, Godfroid E, Fauconnier A, et al. Diagnosis of Helicobacter pylori infection by PCR: comparison with other invasive techniques and detection of cagA gene in gastric biopsy specimens. J Clin Microbiol 1995;33:2752-6.

11. Lee JY, Kim N. Diagnosis of Helicobacter pylori by invasive test: histology. Ann Transl Med 2015;3:10.
H. pylori tanısında kültür tek başına altın standart yöntem olarak kabul edilebilmesine rağmen, tanının doğruluğunun artıırıması için, kültür ile birlikte üreaz testi ve/veya histoloji ve/veya dışkı antijen testleri ve/veya moleküler yöntemler gibi birden fazla yöntemin kullanılması önerilmektedir. H. pylori enfeksiyonlarının tanısında kullanılan farklı özgüllük ve duyarlılığa sahip birçok yöntem arasından yapılacak olan seçim, amaca ve klinik şartlarına göre değişiklik göstermektedir. Malignite düşünülen hastada histopatoloji ön plana çıkarken, tedavinin başarısız olduğu durumlarda suşların tiplendirilmesi ve antibiyotik duyarlılık testlerinin yapılabilmesi için kültür yöntemleri ön plana çıkmaktadır. Sonuç olarak çalışmamııın bulguları, endoskopik yöntemlerin uygulanabildiği durumlarda, erken tanı ve tedavi kararı için hızlı üreaz testi kullanılarak hastalığın tedavisinin planlanabileceğini destekler niteliktedir.

\section{"Tüm yazarlar herhangi bir çıkar çatışması olmadığını kabul ederler."}

12. Laine L, Lewin DN, Naritoku W, Cohen H. Prospective comparison of H\&E, Giemsa, and Genta stains for the diagnosis of Helicobacter pylori. Gastrointest Endosc 1997;45:463-7.

13. Storskrubb T, Aro P, Ronkainen J, et al. Antimicrobial susceptibility of Helicobacter pylori strains in a random adult Swedish population. Helicobacter 2006;11:224-30.

14. Gisbert JP, Abraira V. Accuracy of Helicobacter pylori diagnostic tests in patients with bleeding peptic ulcer: a systematic review and meta-analysis. Am J Gastroenterol 2006;101:848-63.

15. Tankovic J, Chaumette-Planckaert MT, Deforges L, et al. Routine use of real-time PCR for detection of Helicobacter pylori and of clarithromycin resistance mutations. Gastroenterol Clin Biol 2007;31:792-5.

16. Shin CM, Kim N, Lee HS, et al. Validation of diagnostic tests for Helicobacter pylori with regard to grade of atrophic gastritis and/ or intestinal metaplasia. Helicobacter 2009;14:512-9.

17. Aktepe OC, Ciftci IH, Safak B, Uslan I, Dilek FH. Five methods for detection of Helicobacter pylori in the Turkish population. World J Gastroenterol 2011;17:5172-6.

18. Ozcay F, Kocak N, Temizel IN, et al. Helicobacter pylori infection in Turkish children: comparison of diagnostic tests, evaluation of eradication rate, and changes in symptoms after eradication. Helicobacter 2004;9:242-8.

19. Kalem F, Ozdemir M, Baysal B. [Investigation of the presence of Helicobacter pylori by different methods in patients with dyspeptic complaints]. Mikrobiyol Bul 2010;44:29-34. 